\title{
Epidemiology of inflammatory bowel disease in the Province of Granada, Spain: a retrospective study from 1979 to 1988
}

\author{
J F Martínez-Salmeron, M Rodrigo, J de Teresa, F Nogueras, M García-Montero, C de Sola, \\ J Salmeron, $M$ Caballero
}

Department of Gastroenterology, C S

Virgen de las Nieves, and Department of Gastroenterology,

University Hospital,

Granada, Spain

J F Martínez-Salmeron

$M$ Rodrigo

J de Teresa

$F$ Nogueras

M García-Montero

$C$ de Sola

J Salmeron

M Caballero

Correspondence to:

M Rodrigo Moreno

Department of

Gastroenterology, C S Virgen

de las Nieves, Calle Caleta $s / n$,

18014 Granada, Spain.

Accepted for publication 4 February 1991

\begin{abstract}
An epidemiological study of inflammatory bowel disease in the Province of Granada, Spain, was conducted between 1979 and 1988. Altogether, 257 cases were identified: 167 ulcerative colitis, 79 Crohn's disease, and 11 indeterminate colitis. The mean incidence of ulcerative colitis in the 10 year period was $2 / 10^{5}$ and $0.9 / 10^{5}$ for Crohn's disease. This is the first epidemiological study in Spain of the incidence of ulcerative colitis and corroborates the results of an earlier population based study on the incidence of Crohn's disease in Spain. (Gut 1993; 34: 1207-1209)
\end{abstract}

The Province of Granada is part of the Andalusian region (Fig 1). It has 194 municipalities and five cities with a population of over 20000 inhabitants (Motril, Baza, Guadix, Loja, and the capital of the province, Granada). The province has a population of 782568 and a population density of 62 inhabitants per $\mathrm{km}^{2}$.

There are eight hospitals in the province including two private hospitals. Patients with any degree of symptoms are referred to hospital and endoscopic facilities are readily available.

The data used in this study were drawn from the inpatient and outpatient records of these hospitals.

\section{Methods}

Initially every member of the gastroenterology and paediatrics departments were consulted and histopathology, endoscopy, radiology, and diagnostic archives of these hospitals and records of outpatients clinics were searched. Private gastroenterologists were interviewed personally. The data obtained were cross checked, multiple list-

TABLE I Cases and incidence of ulcerative colitis, Crohn's disease, and indeterminate colitis in the Province of Granada, Spain, 1979-88 by sex $(n=257)$

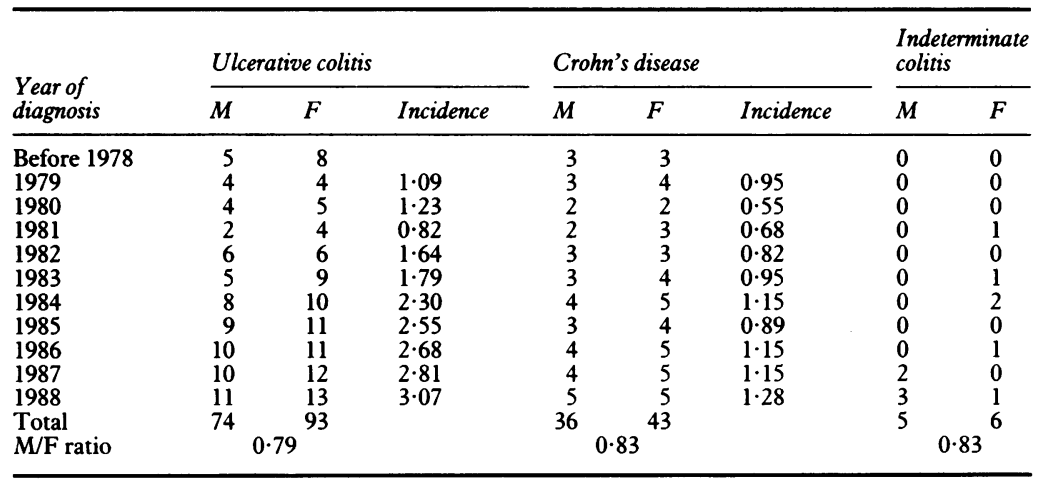

ings were identified and eliminated, and the clinical records of the patient traced. A careful review was made of all records which included International Classification coding for inflammatory bowel disease $(555,556.1,558.9) .{ }^{2}$ Nonresident patients treated in the province were excluded. Finally, all patient medical records were reviewed to confirm or reject the diagnosis of inflammatory bowel disease.

\section{DIAGNOSTIC VERIFICATION}

A total of 341 patients were identified, of whom 84 were excluded. Many had incomplete data (37); others had infective colitis (21), irritable bowel syndrome (18), and diverticulitis (8). Altogether, 167 were confirmed as cases of ulcerative colitis, according to the criteria of Truelove and Witts. ${ }^{3}$ This included the passage of blood and mucus per rectum with or without diarrhoea; a history of remission and relapse/or chronic continuous course for a period of three to six months; and at least one endoscopic examination showing characteristic features of
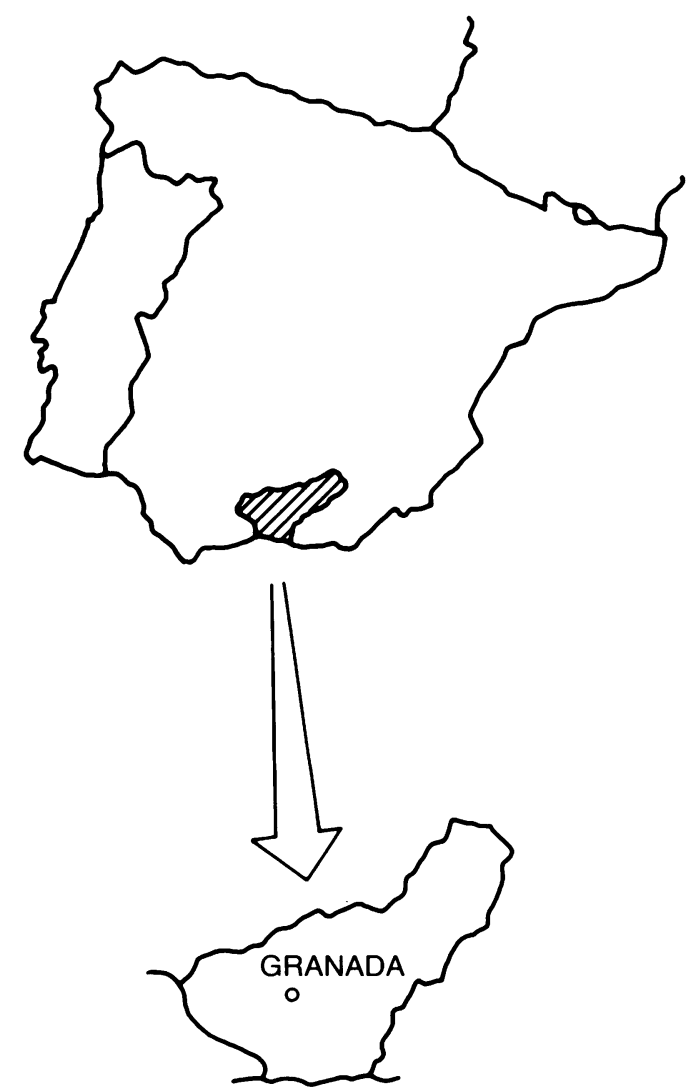

Figure 1: Granada Province, Spain. 


\section{Crohn's disease $\mathrm{AWU}$ Ulcerative colitis}

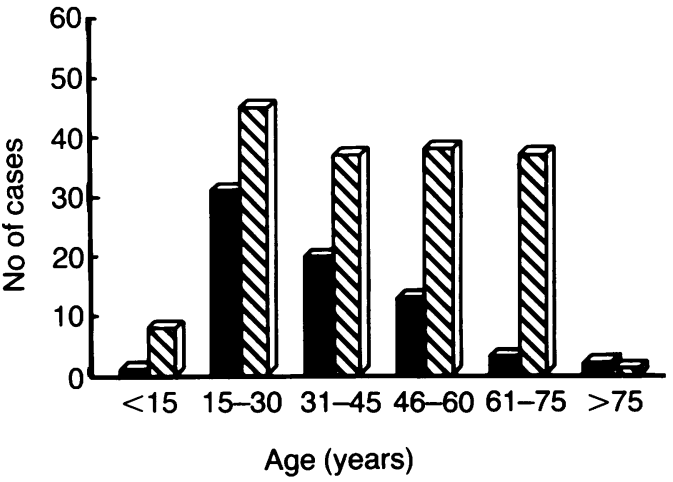

Figure 2: Distribution by age group of Crohn's disease and ulcerative colitis.

inflammatory bowel disease and consistent histopathological features. Lennard-Jones's ${ }^{4}$ criteria were applied to establish a diagnosis of Crohn's disease. Seventy nine patients with Crohn's disease were identified. Eleven cases were classified as indeterminate colitis.

\section{DISEASE SITE}

Of the 167 patients with ulcerative colitis, $42 \mathrm{had}$ disease confined to the rectum, 86 had a left colitis, and 39 pancolitis. Of the 79 patients with Crohn's disease, nine were localised to the ileum, 49 had large bowel disease alone, and 21 had small and large bowel disease.

\section{Results}

Table I gives the distribution by sex for patients with ulcerative colitis, Crohn's disease, and indeterminate colitis and the annual incidence.
TABLE II Incidence of ulcerative colitis and Crohn's disease in some European countries by geographic area and period of study

\begin{tabular}{|c|c|c|c|}
\hline Geographic area & $\begin{array}{l}\text { Period of } \\
\text { study }\end{array}$ & $\begin{array}{l}\text { Incidence } \\
\text { per } 10^{5} \\
\text { of ulcerative } \\
\text { colitis }\end{array}$ & $\begin{array}{l}\text { Incidence } \\
\text { per } 10^{5} \text { of } \\
\text { Crohn's } \\
\text { disease }\end{array}$ \\
\hline $\begin{array}{l}\text { Oxford, England } \\
\text { Cardiff, Wales } \\
\text { Copenhagen County, } \\
\text { Denmark }^{8}\end{array}$ & $\begin{array}{l}1951-60 \\
1968-77 \\
1962-78\end{array}$ & $\begin{array}{l}5 \cdot 2 \\
7 \cdot 2 \\
8 \cdot 2\end{array}$ & $\begin{array}{l}0 \cdot 8 \\
8 \cdot 3 \\
2 \cdot 7\end{array}$ \\
\hline $\begin{array}{l}\text { Regio Leiden, The } \\
\text { Netherlands }\end{array}$ & $1979-83$ & $7 \cdot 0$ & 3.9 \\
\hline $\begin{array}{l}\text { Galicia, Spain } \\
\text { Bologna, Italy }\end{array}$ & $\begin{array}{l}1976-83 \\
1972-73\end{array}$ & $\begin{array}{l}- \\
-\end{array}$ & $\begin{array}{l}0.8 \\
0 \cdot 8\end{array}$ \\
\hline Granada, Spain & $1979-88$ & 2 & 0.9 \\
\hline
\end{tabular}

Of the 167 cases diagnosed as ulcerative colitis, 154 incident cases were seen between 1979 and 1988. The mean annual incidence during this period was 2 per $10^{5}$. We ascertained 79 cases of Crohn's disease ( 73 in the period of study). The mean annual incidence was 0.9 per $10^{5}$. The incidence date was based on date of diagnosis rather than date of onset of disease.

Figure 2 shows the distribution by age for Crohn's disease and ulcerative colitis. There was an increasing incidence for ulcerative colitis but not for Crohn's disease over the study period (Table I, Fig 3A and B).

PREVALENCE

During 1979-88 there were 167 patients with ulcerative colitis resident in the Province of the Granada, giving a prevalence of 21 cases $/ 10$ inhabitants; 79 patients had Crohn's disease with a prevalence of $9 / 10^{5}$.

\section{Discussion}

The incidence of ulcerative colitis is lower in Granada when compared with other western European centres $^{5-8}$ (Table II). The incidence for Crohn's disease was 0.9 per $10^{5}$, and is similar to that found in Galicia, Spain ${ }^{11}$ and Bologna, Italy. ${ }^{13}$

Our data confirm the results of Ruiz Ochoa in

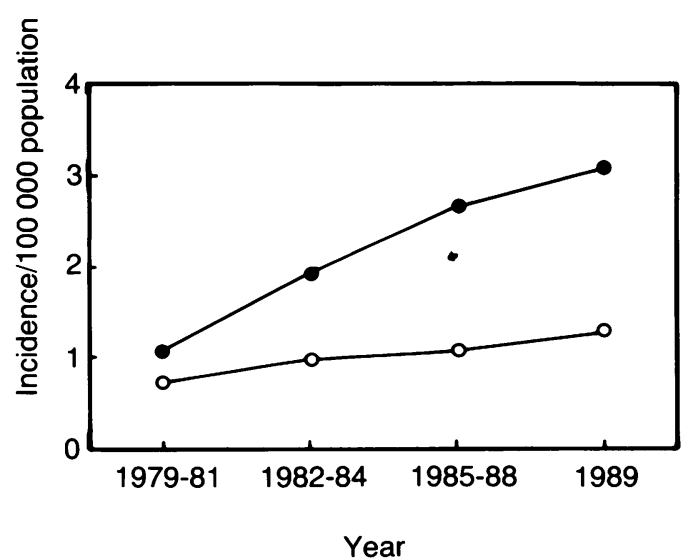

(B)

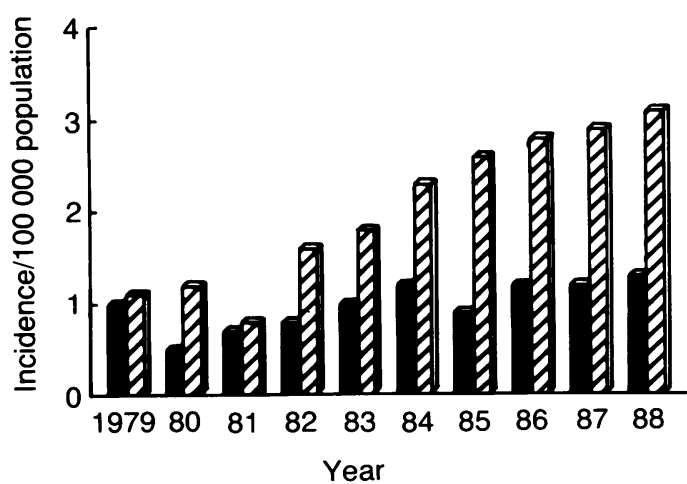

Figure 3: Incidence rates per 100000 population of inflammatory bowel disease. 
Galicia" concerning the incidence of Crohn's disease. These are the only two population based surveys that have been reported from Spain. The incidence is higher than in other studies from Spain which were not population based. ${ }^{13-15} \mathrm{~A}$ review of current world publications suggests that inflammatory bowel disease is most common in northern Europe, is becoming commoner in southern Europe, and is least common in other areas of the world.

Comparisons of rates between different areas are subject to certain limitations. The medical care system varies from area to area. This variation includes diagnostic criteria, diagnostic trends, and improvements in diagnostic technology. The impact of changing diagnostic practices cannot be ignored. It is important to register ulcerative colitis and Crohn's disease patients and review both groups. ${ }^{16}$

The time trend observed in incidence over the 10 year period suggests that the incidence of ulcerative colitis is increasing but not that for Crohn's disease. These findings contrast with other European studies. ${ }^{17}$

Food consumption patterns vary in different countries. In northern Europe people eat more meat, and in the south more vegetables and possibly more fat and these factors may be important in pathogenesis.

We thank the following for their collaboration: J Pérez (Santa Ana Hospital, Motril), J García (General Hospital, Baza), F Pechuan (Militar Hospital, Granada), R Martín-Vivaldi, J Pleguezuelos, E Lacárcel, $R$ Llavero, E Baeyens, $M$ Uariachi (C S Virgen de las Nieves, Granada). We thank Dr A S Peña (Leiden) and Dr Shivananda (Rotterdam) for advice, and $\mathrm{Mr}$ M J Muñoz and Ms Gamiz for help in preparing the manuscript.
1 Boletin oficial de la provincia de Granada. Circular 11/87. 1987; 81: 2-3.

2 International classification of diseases. 9th revision. Clinical modification. Vol 1 . Washington DC: US Public Health Service, US Government Printing Office: 1980.

3 Truelove SC, Witts C. Cortisone in ulcerative colitis. $B M \mathcal{J}$ 1955; 2: 1041-8

4 Lennard-Jones JE. Regional enteritis (Crohn's disease). Definition and diagnosis. Skandia International Symposia: regional enteritis. Stockholm: Nordiska Bolchandeln Forlag, 1970: 108-9.

5 Evans JG, Acheson E. An epidemiological study of ulcerative colitis, and regional enteritis in the Oxford area. Gut 1965; 6 : 311-24.

6 Morris J, Rhodes J. Incidence of ulcerative colitis in the Cardiff region 1968-1977. Gut 1984; 25: 846-8.

7 Rose JDR, Roberts GM, Williams G, Mayberry JF, Rhodes J. Cardiff Crohn's disease jubilee: the incidence over 50 years. Gut 1988; 29: 346-51.

8 Binder U, Both H, Hansen PK, Hendriksen C, Kreiner S, Top-Pedersen K. Incidence and prevalence of ulcerative colitis and Crohn's disease in the Copenhagen country. 1962 to 1978. Gastroenterology 1982; 83: 563-8.

9 Shivananda S, Peña AS, Mayberry JF, Ruitemberg ES, Hoedemaeker PhJ. Epidemiology of proctocolitis in the region of Leiden. The Netherlands. Scand 7 Gastroenterol 1987; 22: 993-1002.

10 Shivananda S, Peña AS, Weterman IF, Mayberry JF, Ruitemberg EJ, Hoedemaeker PhJ. Epidemiology of Crohn's disease in regio Leiden. The Netherlands. Gastroenterology 1987; 93: 966-74.

11 Ruiz-Ochoa V, Potel S. Crohn's disease in Galicia, Spain 1968 1982. Front Gastrointest Res 1986; 53: 94-101.

12 Lanfranchi GA, Michelini A, Brignola C, Campieri M, Cortini C, Marzio C. Uno studio epidemiologico sulle mallatie inflamatorie intestinali nella provincia di Bologna. $G$ Clin Med 1976; 57: 235-45.

13 Martinez G, Fernandez Y, Rodrigo Saez L, Martinez E Estudio epidemiologico de la enfermedad de Crohn en la región asturiana. Rev Esp Enferm Apar Dig 1983; 63: $534-41$

14 Pajares JM, Rodriguez S, Mati J. Prevalencia de la enfermedad de Crohn en la zona central de España (ambas Castillas. La Mancha Cantabria y Rioja). Estudio epidemiologico cooperativo de la Asociación Castellana de Aparato Digestivo (ACAD). Rev Esp Enferm Apar Dig 1987; 71 : 313-7.

15 Carcía Paredes J, Pajares García JM. Crohn's disease in the central area of Spain. In: Peña AS, Weterman IT, Booth CC, Strobel W, eds. Recent advances in Crohn's disease. The Hague: Martinus Nijhoff, 1981: 168-73.

16 Calkins BM, Mendeloff AI. Epidemiology of inflammatory bowel disease. Epidemiol Rev 1986; 8: 60-91.

17 Kyle J, Stark G. Fall in the incidence of Crohn's disease. $G u$ $1980 ; 31: 340-3$ 